\title{
RUANG PERSONAL SEBAGAI PELARIAN DARI MODERNITAS
}

\author{
Sandi Jaya Saputra ${ }^{1}$ Justito Adiprasetio $^{2}$ \\ ${ }^{1}$ Program Studi Jurnalistik, Fakultas Ilmu Komunikasi, Universitas Padjadjaran. \\ ${ }^{2}$ Program Studi Jurnalistik, Fakultas Ilmu Komunikasi, Universitas Padjadjaran. \\ Sandijayasaputra85@gmail.com \\ justitoadiprasetio@gmail.com
}

\begin{abstract}
This article discusses personal and communal spaces as an escape from modernity by using the medium of documentary photography and semiology Barthesian. The goal of is to demonstrate how personal and communal spaces in everyday reality is connected with the narrative of modernity. In this article, the authors show the relation of daily practice that is trivial with the great discourse of modernity in kostan contained in Bandung is oppositional and counterproductive. This study shows that activities in the personal and communal spaces, representing leisure and uselessness at the extreme level when viewed from the measure of efficiency and effectiveness of the spirit of modernism.
\end{abstract}

\begin{abstract}
ABSTRAK
Dalam artikel ini penulis membedah keseharian Ruang Personal sebagai Pelarian dari Modernitas dengan mengunakan medium fotografi dokumenter dan semiologi Barthesian. Tujuannya adalah untuk mendemonstrasikan bagaimana ruang personal dan komunal dalam realitas keseharian terhubung dengan narasi modernitas. Dalam artikel ini, penulis menunjukan relasi praktik keseharian yang remeh temeh dengan wacana besar modernitas di kostan yang terdapat di Bandung bersifat oposisif dan kontraproduktif. Penelitian ini menunjukkan bahwa aktivitasaktivitas yang terdapat di ruang personal, merupakan representasi leisure dan ketidak-bergunaan di level ekstrim bila dipandang dari ukuran efisiensi dan efektifitas semangat modernisme.
\end{abstract}

Kata-kata Kunci: Foto dokumenter, fotografi, identitas, personal. 


\section{PENDAHULUAN}

Modernisme telah menyeret manusia untuk terus mengencangkan ikat pinggang, berupaya menggapai efisiensi dan efektifitas dalam berbagai aspek kehidupan. Marx membangun tegangan basis dan suprastruktur dari asumsi modernisme: bahwa, semua berbagai aspek ideologis yang terdapat di dalam dimensi supra-struktur adalah pantulan dari tindak ekonomi manusia ketika berupaya memenuhi kebutuhan hidupnya. Bagi kaum Marxistorthodox, ekonomi adalah pondasi utama, sedangkan aspek-aspek ideologis: budaya, institusi, struktur politik, peran, ritus, negara, dan keseharian kita akan mengikuti bentuk pondasi yang ada. Dalam kacamata Marxist-orthodox pula, kita dapat menghakimi bahwa keseharian dan ruparupa yang berkait dengan itu, adalah bagian yang integral terhadap upaya pemenuhan ekonomi yang efisien dan efektif. Dalam pandangan marxist-orthodox, hasrat hedonis perlahan-lahan akan tersingkir; waktu luang tidak akan diisi oleh upaya untuk mengejar kenikmatan, dan apa yang bersisa adalah penggunaan secara efisien dan efektif dari waktu luang untuk menopang ekonomi di hari-hari kerja.

Namun semua tidaklah bekerja senaif itu. Barthes dengan perangkat metodologinya, pengembangan semiologi Saussurean menunjukkan bahwa problem dalam gaya hidup dan dunia keseharian dengan keekonomian tidaklah se-linear itu. Barthes mendemonstrasikan bagaimana berbagai aspek keseharian - salah satu contohnya adalah bagaimana kultur borjuis meminum wine, tidaklah bersifat kausal dengan fungsinya, di mana meminum wine dapat mengantarkan pada masalah kesehatan, dst tidak lah dipengaruhi langsung oleh sifat- sifat ke-ekonomiannya, namun dipengaruhi oleh bagaimana kelas borjuis secara historis membangun mitos yang melekatkan wine dengan gaya hidup mewah, dst. Kita dapat membaca uraian lebih jauh terkait bagaimana distingsi yang terbangun di sekitar habitus meminum Wine, dari sosiolog Pierre Bourdieu. Kultur meminum wine tidak terlepas dari aspek ke-ekonomian namun ia adalah hasil tegangan yang tidak sederhana di dalam supra-struktur, dan juga basis yang menjadi wilayah di mana habitus itu bekerja.

Tegangan yang tidak sederhana, karena walaupun ia berpola membangun habitus, ia tersusun dari narasi-narasi kecil yang terserak dan tidak pernah benar-benar simetris antara satu sama lain. Kecenderungan memotret habitus dari kacamata dengan perspektif besar adalah hal yang coba ditantang oleh tulisan ini. Tulisan ini berupaya untuk melihat keseharian dari bawah, dari narasi-narasi kecil yang kerapkali luput dilihat oleh kajian-kajian sosiologis yang berkutat dalam perspektif bingkai besar.

Subjek dari penelitian ini adalah situasi yang terjadi disalah satu kostan di Bandung. Di mana mereka yang tinggal di kamar kos Bandung tersebut adalah mereka yang berasal dari kalangan mahasiswa maupun kelas pekerja. Dengan medium fotografi dan semiologi, penulis berupaya menunjukkan bagaimana narasi-narasi besar modernisme tidak-lah benar-benar bisa mendikte ruangruang keseharian mereka yang berada dan berputar di dalam roda-roda modernisme. Kamar kos adalah ruang personal dan komunalitas dan menjadi ruang bersahaja yang menjadi field dimana leisure mereka dipraktikkan, dan merupakan sarana eskapis dari rutinitas kerja, vis a vis dengan corakcorak kerja di mana semua hal dan aktivitas 
harus dilakukan dengan efisien dan efektif. Ruang Personal sebagai Pelarian dari Modernisme.

\section{METODE PENELITIAN}

Merujuk pada subjek penelitian, ini adalah proyek mengenai bagaimana penulis di kostan. Bagaimana realita kamar dan objek-objek yang berada dalam kamar penulis dipindahkan ke medium representasi, yaitu fotografi. Teori Roland Barthes banyak menjadi rujukan apabila membicarakan tentang representasi yang representasinya merujuk kepada proses realitas dan disampaikan dalam komunikasi, via kata-kata, bunyi, citra, atau kombinasinya (Fiske, 2004: 282). Representasi juga disebut sebagai cara bagaimana media menginterpretasikan dunia, atau realitas eksternal lainnya (Rayner, 2001: 63). Trifonas menyebutkan representasi sebagai wahana yang dengannya dua hal yang tidak berkaitan dipersatukan untuk mengacu pada sebuah konsep (Trifonas, 2003: 63). Pada dasarnya pandangan representasi ini memiliki semacam korespondensi dengan sesuatu yang direpresentasikan.

Untuk menentukan bagaimana representasi dalam mempersoalkan kamar kos penulis pada judul Ruang Personal sebagai Pelarian dari Modernisme adalah seperti halnya yang diungkapkan Barthes. Barthes berpendapat bahwa foto dapat membantu untuk mengembangkan subjektivitas manusia dengan "membacanya" (Sunardi, 2004: 163-164). Pembacaan yang dimaksud adalah pembacaan

Wacana keseharian dalam karya penulis adalah representasi ruang personal dalam keseharian penulis di kos, wacana merupakan salah satu kata kunci dalam pendekatan-pendekatan kontemporer, terutama postrukturalisme.

Penulis menggunakana pendekatan foto dokumenter dalam melihat representasi Ruang Personal sebagai Pelarian dari Modernisme. Hal tersebut karena foto dokumenter secara penggambaran lebih dekat dengan realita keseharian itu sendiri. Keseharian yang banal bersifat trivial, terlihat menyimpan misteri yang perlu disingkapkan. Karakter foto dokumenter secara ideologis lebih 'demokratis' karena secara representatif, tidak terlihat menggunakan teknik yang canggih dan memiliki kecendrungan lebih 'natural.'

Pendekatan foto dokumenter pada proyek ini mengunakan teknik still life, maka penulis menggunakan kamera digital medium format dengan merek phaseone yang popular dalam pemotretan still life. Tujuannya adalah untuk menghasilkan gambar yang tetap natural dalam merepresentasikan wacana keseharian yang menjadi bentuk baru dalam realitanya, yang penulis bangun menjadi bentuk gambar kotak, mengikuti karakter kamera tersebut. Obyek obyek yang dibidik adalah benda yang ada di sekeliling bahkan keseharian manusia.

\section{HASIL DAN PEMBAHASAN}

Hasil tulisan ini menjelaskan bagaimana Ruang Personal sebagai Pelarian dari Modernitas. Menurut Thomas Weski bahwa cara memilih dan membekukan sebuah citraan akan dunia realitas ke dalam sebuah gambar dengan latar gagasan artistik sebagai kerangka dalam konteks visual art. Thomas Weski memandang karya foto dalam koridor seni kontemporer di mana dalam karyakarya foto yang kini cenderung pada permasalahan makna 'teks' dan konsep, dari pada permasalahan foto itu sendiri. Fotografi 
dalam era kontemporer sudah tidak lagi membicarakan representasi, tetapi lebih jauh lagi, yaitu fotografi mempermasalahkan persoalan seperti layaknya sebuah karya seni pada umumnya. Hal ini menawarkan dan mengajak para pengamatnya untuk fokus pada subjek-subjek yang berbeda dengan sebuah cara pandang baru yang lebih terbuka (Demos, 2006: 7).

Penulis menyuguhkan bagaimana problematika keseharian tersebut dalam medium fotografi. Apa yang ada di kostan penulis, disadari atau tanpa disadari adalah potret kehidupan kontemporer saat in. Dalam hal ini, bagaimana penulis melihat kamar pribadinya sebagai representasi dari identitas yang terbentuk oleh konsekuensi dari modernisme.

Untuk membaca karya ini, Perlu diperhatikan konsep struktur dan superstruktur. Struktur adalah sesuatu yang sudah melekat dalam diri penulis atau sesuatu yang dasar atau dalam konteks Ruang Personal sebagai Pelarian dari Modernitas adalah wilayah domestik yaitu kamar penulis, wilayah domestik yang ada dalam kamar kos.

Unsur tidak terduga dalam melihat persoalan identitas dan ruang yang penulis eksplorasi, dalam Ruang Personal sebagai Pelarian dari Modernitas adalah identitas yang terkonstruksi dari struktur dan super struktur. Maka dari itu penulis menggambarkan benda-benda keseharian yang setiap hari digunakan dan dilihat oleh penulis, serta bagaimana sudut-sudut kamar melengkapi dan memberikan ruang ketajaman dalam melihat identitas tersebut. Penulis 'merekayasa' tampilan dalam merepresentasikan benda-benda dan sudut kamar penulis. Yang dimaksud 'merekayasa' benda keseharian dan 'sudut kamar' dalam Ruang Personal sebagai
Pelarian dari Modernitas adalah motif kesenian. Tujuannya menghadirkan puitisasi, pelebihan, dan penerjemahan dari kebutuhan indrawi yang berakar pada kebutuhan biologis manusia. Alasannya, kebutuhan biologis manusia memiliki sensasi-sensasi yang sangat kuat, untuk mempertajam seleranya, Katya Mondoki dalam bukunya Everday Aesthetics (2007).

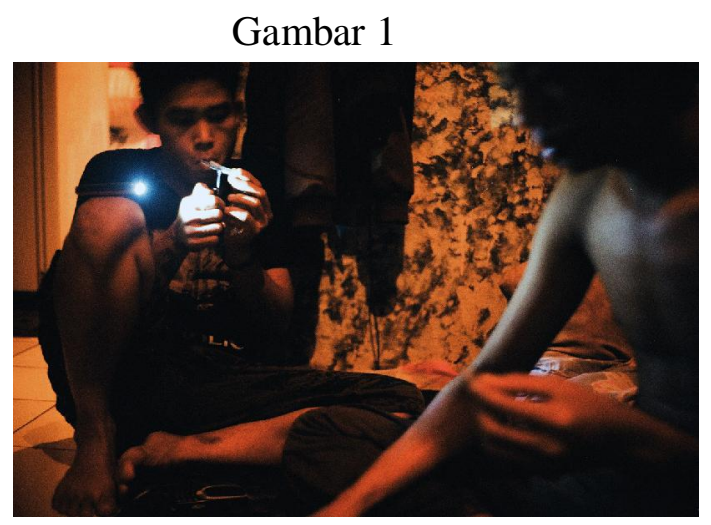

Aktivitas merokok di kostan adalah kegiatan personal sekaligus kolektif. Kegiatan yang bisa dilakukan secara personal di bilik kamar masing-masing, tapi dalam momen-momen tertentu ia dilakukan bersama dengan mereka yang bernaung di bawah atap yang sama. Berbagi rokok, berbagi korek adalah penanda kolektivisme dari kegiatan merokok bersama.

Perbincangan secara sporadis dapat muncul dalam kegiatan merokok kolektif. Keluhan soal kehidupan sehari-hari, perbincangan remeh-temeh, juga perbincangan serius dapat muncul di antara aktivitas merokok. Aktivitas merokok kolektif adalah aktivitas yang sangat terbuka untuk segala hal, ia dapat dilakukan sembari bermain game atau musik.

Secara ideologis, kegiatan merokok memiliki posisi yang vis-à-vis dengan semangat modernisme, karena merokok adalah tindak hedonis yang tidak 
menyehatkan namun menghasilkan pleasure yang berpotensi menjadi candu. Kegiatan merokok yang dilakukan bersama-sama adalah representasi kolektif dari tindak hedonisme, ia menjadi kegiatan eskapis dari keseharian, namun dilakukan bersama.

\section{Gambar 2}

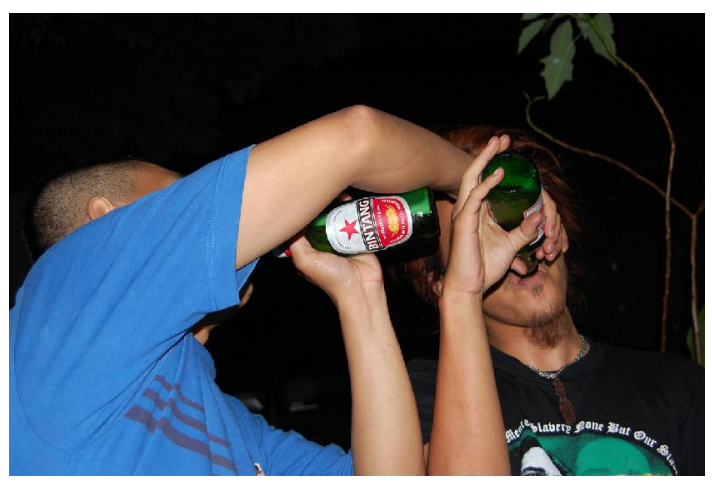

Bir adalah minuman yang menjadi penanda aktivitas waktu luang. Alkohol dengan dosis rendah yang terkandung dalam bir, membuat bir adalah minuman yang dikonsumsi pada waktu-waktu dengan rentang waktu yang tidak pendek. Berbeda dengan alkohol dengan dosis tinggi, meminum bir adalah aktivitas kolektif yang memungkinkan di sela-selanya masih terjadi perbincangan-perbincangan yang panjang.

Secara ideologis, bir adalah representasi dari minuman kelas menengah ibukota. Ia berbeda dengan alkohol jenis lain, lebih mahal ketimbang minuman alkohol tradisional atau minuman oplosan, namun tidak semahal alkohol impor. Aktivitas minum bir adalah representasi ideologis dari leisure kelas menengah kota besar di Indonesia.

Dalam konteks yang berbeda, bir dipandang sebagai minuman haram bila dilihat dari perspektif islam, agama mayoritas di Indonesia. Minuman beralkohol berelasi dengan aktivitas berdosa dan buruk, di mana dapat mengantarkan pada kondisi mabuk yang berpotensi menjadi penyebab prilaku jahat. Minuman beralkohol kerapkali berelasi dan direlasikan dengan aktivitas bandit atau premanpreman. Pada posisi tersebut aktivitas meminum bir adalah jeda atau eskapis dari doxa yang berlaku dalam peta ideologi dominan di Indonesia. Meminum bir adalah laku untuk tidak tunduk pada ideologi agama Islam.

Mabuk-mabukan hingga jackpot adalah habitus kelas menengah. Berbeda dengan bagaimana posisi alkohol bagi kelas elit, di mana aktivitas meminum alkohol seperti Wine adalah bagian gaya hidup yang ber-eratan dengan ideologi "kemewahan", dalam posisi ini meminum bir hingga puncak mabuk, adalah bagian dari laku pencarian kenikmatan. J ackpot adalah kondisi yang dituju, sebagai puncak dari aktivitas meminum alkohol itu. J ackpot atau muntah adalah penanda puncak dari laku hedonisme.

$$
\text { Jackpot dalam posisi ideologis }
$$
adalah akhir dari eksapisme atas rutinitas dunia, kejengahan atas rutinitas di hari-hari kerja. Ia adalah tujuan, awal dari ketidaksadaran yang diinginkan, puncak dari pelarian untuk melupakan aktivitas keseharian. Jackpot adalah penanda atas penolakan semangat modernisme

\section{Gambar 3}

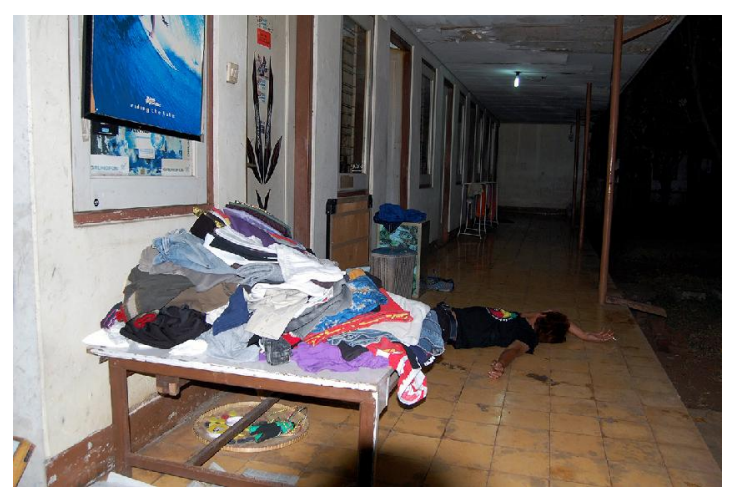


Seperti disebutkan sebelumnya bahwa tertidur atau ketidaksadaran setelah jackpot, puncak dari mabuk, adalah tujuan yang ingin dicapai. Dalam kondisi-nya, ketidaksadaran dapat terjadi di mana saja di kostan. Bergelimpangan di halaman, ubin, atau di kasur. Tempat tidaklah penting, tidak menjadi signifikan, dalam kondisi tersebut.

Pada ketidaksadaran, egaliterianisme dan kebebasan secara simbolik terepresentasi. Tidak hanya hasrat atas mabuk sendiri merepresentasikan laku kebebasan dan otonomi atas diri. Namun tempat yang secara acak dapat menjadi lokasi puncak dari kondisi mabuk adalah representasi utama atas kemungkinan akan kebebasan tersebut.

\section{Gambar 4}

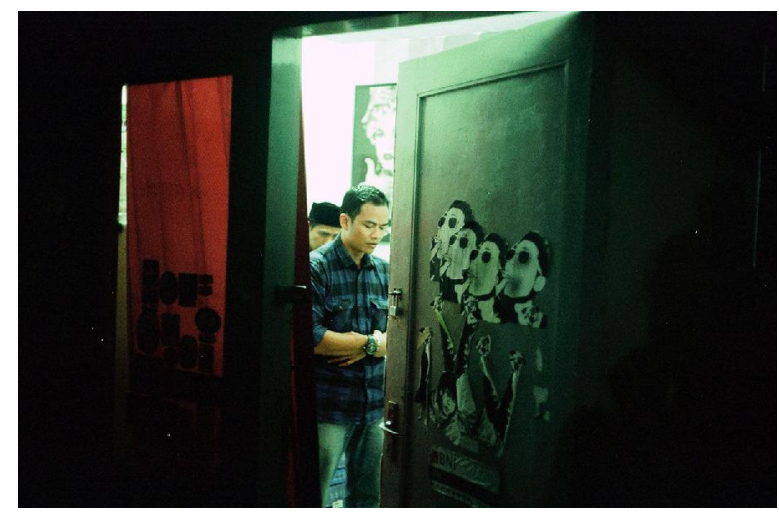

Di kostan yang sama, tempat di mana sebagian orang mengisi leisure time mereka dengan mabuk hingga muntah, terdapat sebagian orang lain yang menjalankan ibadah shalat. Shalat dijalankan di suatu kamar yang terpisah dengan mereka yang minum dan mabuk. Aktivitas shalat sendiri tidak dilakukan secara personal, juga kolektif. Pada posisi yang kontradiktif, bahwa aktivitas ekstrim melanggar hukum agama Islam dilakukan di wilayah yang sama dengan prilaku menjalankan perintah tuhan, shalat.

Kontradiksi yang menunjukkan bentuk-bentuk toleransi yang hanya bisa dipahami oleh mereka yang menjalani dan beraktivitas di ruang tersebut. Secara ideologis, toleransi ada di level ekstrim bahwa mereka akan menjalankan aktivitas masing-masing tidak menggubris satu sama lain, namun jauh dari bentuk totaliterianisme defensif di mana tidak ada percakapan di antaranya, mereka yang shalat, maupun mereka yang mabuk, tetap terhubung sebagai orang-orang yang menghuni bangunan yang sama, dan membuka ruang satu-sama lain. Bahkan aktivitas shalat pun dilakukan dengan pintu terbuka.

\section{SIMPULAN}

Setelah menelusuri berbagai paparan di atas, maka terdapat tiga simpulan. Pertama medium fotografi adalah medium yang tepat untuk membedah keseharian karena unsur dalam keseharian sepenuhnya tidak rasional, maka mewacanakan keseharian secara rasional justru menghilangkan keunikan subtansi keseharian tersebut (Featherstone, 1995: 55). Dengan, medium fotografi dokumenter yang memiliki sifat 'terlihat' nyata sebagai medium representasi ideologis.

Kedua adalah ruang personal yang merupakan kostan dan menjadi subjek penelitian menunjukkan diri sebagai ruang yang berisi aktivitas antitesis dari modernitas. Aktivitas-aktivitas yang terdapat di ruang personal dan komunal kostan, merupakan representasi leisure dan ketidakbergunaan di level ekstrim bila dipandang dari ukuran efisiensi dan efektifitas semangat modernisme.

$$
\text { Ketiga, bagaimana penulis }
$$
merepresentasikan Ruang Personal sebagai 
Pelarian dari Modernitas melalui medium fotografi dokumenter adalah. Dengan begitu tujuan pencapaian estetik dan bagaimana wilayah personal dapat direpresentasikan dengan tepat. Georg Simmel (1858-1918) berpendapat dalam menampilkan kembali narasi kecil atas kontruksi modernitas, maka keseharian modern dialami sebagai bombardemen sensoris yang agresif dan mengaburkan arah (disorienting).

\section{DAFTAR PUSTAKA}

Barthes, R. 2013. M ythologies. New York: Hill and Wang.

Bourdieu, P., Nice, R., \& Bennett, T. 2015. Distinction: A social critique of the judgement of taste. New York: Routledge.

Demos, T.J. 2006. Vitamin Ph: New Perspectives in Photography. New York: Phaidon Press

Featherstone, M. 1995. Undoing Culture: Globalization, postmodernization abd identity. London: Sage

Fiske, J. 2004. Cultual and Communication Studies: Sebuah Pengantar Paling Komprehensif. Yogyakarta: Jalasutra

Katya, M. 2007. Everday Aesthetics. Ashgate England.

Rayner, P. Peter, W, Stephen, K. 2001. Media Studies: The Essential Introduction. New York: Routledge

Sunardi, S.T. 2004. Semiotika Negativa. Yogyakarta : Penerbit Buku Baik

Trifonas, P. P. 2003. Seri Posmodern: Barthes dan Imperium Tanda. Yogyakarta: Penerbit Jendela 